KERRY MCSWEENEY is a member of the Department of English at Queen's University and former Editor of Queen's Quarterly.

The central importance of naturalistic vision - of a sense of man's life as part of nature - is emphasized in this study of the poetry of Tennyson and Swinburne. In tracing this vision, Professor McSweeney makes a series of qualitative distinctions leading to a revaluation of the achievements of both poets.

McSweeney begins with an examination of Swinburne's critical and creative response to Tennyson, revealing Swinburne's perception of the effect that Tennyson's suppression of naturalistic vision and his consequent overemphasis on morality and metaphysical speculation had on his poetry. A brief discussion of Tennyson's response to Swinburne is followed by an analysis of the literary climate of the 1820 and 1830 , necessary for an understanding of the central feature of Tennyson's artistic development: the complex mutation which transformed him from a wholly Romantic poet into a largely Victorian one.

Tracing the development of Tennyson's poetry, McSweeney examines some of the best-known works, including 'The Lady of Shalott,' 'The Hesperides,' 'The Two Voices,' and 'The Lotos Eaters,' and supplies analyses of In Memoriam and Idylls of the King.

A thematic overview of Swinburne's canon generates an examination which substantiates the argument that his poetry, contrary to George Meredith's opinion, possesses an 'internal centre.' Close readings of four of the most important poems of the second half of Swinburne's career, By the North Sea, Tristram of Lyonesse, A Nympholept, and The Lake of Gaube, are included.

This book places the two poets in the central tradition of Romantic naturalism and will be of interest to specialists in nineteenth-century literature as well as those interested in English literature in general. 



\section{KERRY MCSWEENEY}

\section{Tennyson and Swinburne as Romantic Naturalists}

UNIVERSITY OF TORONTO PRESS

Toronto Buffalo London 
(C) University of Toronto Press 1981

Toronto Buffalo London

Printed in Canada

Reprinted in 2018

ISBN 0-8020-2381-9

ISBN 978-1-4875-7875-6 (paper)

\section{Canadian Cataloguing in Publication Data}

McSweeney, Kerry, 1941-

Tennyson and Swinburne as romantic naturalists

Includes index.

ISBN 0-8020-2381-9

1. Tennyson, Alfred Tennyson, Baron, 1809-1892-

Criticism and interpretation. 2. Swinburne,

Algernon Charles, 1837-1909-Criticism and interpretation. 3. English poetry - 19th century -

History and criticism. 4. Romanticism - England.

I. Title.

PR5581.M37 821'.809145 c81-094066-3 
To the Memory of my Mother

Lucy Kingen McSweeney 
